\title{
Lexis
}

Journal in English Lexicology

13 | 2019

Lexicon, Sensations, Perceptions and Emotions

\section{Feel and have a feel: perceptions and emotions represented}

Stéphanie Béligon

\section{(2) OpenEdition}

Journals

\section{Electronic version}

URL: http://journals.openedition.org/lexis/2797

DOI: $10.4000 /$ lexis. 2797

ISSN: 1951-6215

\section{Publisher}

Université Jean Moulin - Lyon 3

\section{Electronic reference}

Stéphanie Béligon, «Feel and have a feel: perceptions and emotions represented », Lexis [Online], 13 | 2019, Online since 14 March 2019, connection on 20 April 2019. URL : http:// journals.openedition.org/lexis/2797; DOI : 10.4000/lexis.2797

This text was automatically generated on 20 April 2019.

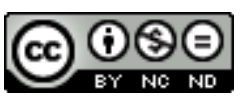

Lexis is licensed under a Creative Commons Attribution-NonCommercial-NoDerivatives 4.0 International License. 


\title{
Feel and have a feel: perceptions and emotions represented
}

\author{
Stéphanie Béligon
}

\section{Introduction}

1 This contribution analyzes the verb feel in its use as a copula and the substantive feel in the structure X HAVE a(n) ADJECTIVE feel and X HAVE a(n) ADJECTIVE feel to it in American English. The two constructions refer to perception - in particular to tactile perception and impressions, and seem at first sight to be semantically equivalent when their grammatical subject designates the object perceived. Utterances such as The room feels cozy and The room has a cozy feel are very close semantically, in the same way as the sentences The flower smells sweet and The flower has a sweet smell, for instance. However, the very existence of the two phrases calls into question a perfect semantic equivalence and, as we shall see, the adjectives entering these constructions are not always the same, which suggests that the two structures do not convey the same representation of perception.

2 This contribution is based on data drawn from the Corpus of Contemporary American English (COCA) and consists of a qualitative analysis of the adjectives occurring in the sequences feel ADJECTIVE and HAVE a(n) ADJECTIVE feel. The hypothesis defended here is that the verb is connected with subjective experience anchored in a particular situation whereas the substantive is at one remove from subjective experience, and refers to codified sensations and emotions.

3 The first section of this contribution deals with the state of the question; secondly, the paper takes stock of the evolution of the verb and the noun feel and shows that the meanings under scrutiny are relatively recent. Thirdly, examples of the two constructions extracted from the COCA are analyzed; finally, the last section compares HAVE a(n) ADJECTIVE feel and HAVE a(n) ADJECTIVE feel to it. 


\section{Definition and evolution of the lexemes}

\subsection{The verb feel}

4 experiencers; the Online Etymology Dictionary defines Old English felan as "to touch or have a sensory experience of; perceive, sense (something)" and adds that in late Old English, it meant "have a mental perception".

5 According to the same dictionary:

[s]ense of "be conscious of a tactile sensation, sense pain, pleasure, illness, etc.; have an emotional experience or reaction," developed by c. 1200 , also "have an opinion or conviction;" that of "to react with sympathy or compassion" is from mid-14c. Meaning "to try by touch" is from early $14 \mathrm{c}$.

The Oxford English Dictionary (OED) reports that the use of feel as a copula, defined as "To be consciously perceived (esp. through the sense of touch) as having the specified quality; to produce the sensation or give the impression of being; to seem", appeared several centuries later, and the first recorded use dates back to 1581 ("The hande... feeling to bee rough"); the first occurrence of the copular verb referring to a general impression, and not to the sense of touch, appeared as late as the $19^{\text {th }}$ century, and the dictionary quotes one of E. B. Browning's Last Poems, published in 1862, as its first occurrence ("Then one weeps, then one kneels! God, how the house feels!"). The late appearance of that meaning is noteworthy and is therefore the object of various analyses, such as C. Lacassain's [2012] analysis:

Il apparaît que, pour chacun des cinq verbes copules [look, sound, smell, taste et feel], il existe dans la modalité perceptive concernée un nom qui leur correspond. Notre hypothèse est que l'usage langagier aurait fini par sélectionner, comme verbe copule, le verbe qui, dans chaque modalité, a un nom apparenté. Elle est corroborée par le fait que les noms correspondant aux cinq verbes copules sont apparus en diachronie soit avant l'emploi copule du verbe (look, sound, taste, feel), soit en même temps (smell). On pourrait même envisager qu'il y ait eu deux phénomènes de conversion: les verbes de perception directe sont apparus en premier dans le langage, puis un processus de conversion nominale a donné naissance à des noms correspondants. [...] Puis, à partir des noms existants, un second processus de conversion, verbale cette fois, a eu lieu, générant les verbes de perception copules.

\subsection{The substantive feel}

However, it is worth noticing that although the substantive feel emerged in the $13^{\text {th }}$ century, it first meant "sensation, understanding" (Online Etymology Dictionary), whereas its earliest use in the sense of "The feeling or sensation produced by an object or material when touched (considered as if a property of the object or material)" (OED) dates back to the $18^{\text {th }}$ century ("We must judge then by the Feel of the Surface of the Bone", 1739). Meanings referring to "The way in which something responds to handling or use; the tactile response or impression produced by something (esp. a vehicle or other device) when handled, operated, or acted upon" (OED) and to "The impression or effect produced on a person by a place, situation, etc.; the quality of feeling similar to, or resembling, a specified thing" (OED) did not appear until the late $19^{\text {th }}$ century. According to the OED, the first use of those meanings dates from 1889 ("Mr. Fellowes... used to advise young 
aspirants to keep a ball perpetually about them; to be always tossing it about and throwing it, so as to get thoroughly used to the feel of it") and 1892 ("Some of the men [in the workshop are] not on speaking terms with... others, and the whole feel of the place [is] miserable and unhappy") respectively.

In other words, the substantive feel came to convey the meaning of objective property several centuries after the verb, so that it probably results from the verbal meaning in question. One may therefore surmise that another conversion is at play here and that this meaning derives from that of copular feel.

\section{State of the question}

Many authors deal with the conversion (or zero-derivation) of verbs of perception yielding a noun (A. Wierzbicka [1982], B. Cetnarowska [1993], N. Gisborne [1993] or I. Plag [2003]), in particular in the construction have a(n) (ADJECTIVE) feel. However, most of them focus above all on the periphrastic equivalent of the verbs look / smell / feel / taste in their active sense (Have a look at that! = Look at that!). Other authors (cf. J.-C. Souesme [2015], for instance) study the role of each of the components of those structures (have and $a(n)$ ), but do not compare the nouns and the verbs they derive from. However, some of those studies do contain observations that are directly relevant to the present study.

\subsection{Common points between the verb and the substantive}

As C. Lacassain [2012] notes, feel as a copula verb can be glossed by the phrase have a(n) ADJECTIVE feel:

[C]hacun des verbes à emploi copule peut être glosé comme dans les énoncés en (5)

[...]

(5) (a) The house looks nice = the house has a nice look

(b) The music sounds good = the music has a good sound

(c) The reeds smell sweet $=$ the reeds have a sweet smell

(d) The coffee tastes good = the coffee has a good taste

(e) The table feels leathery $=$ the table has a leathery feel

11 Nevertheless, this semantic equivalence is valid as a first approximation but deserves a more detailed analysis.

\subsection{Meaning of copular feel}

C. Lacassain [2012] and C. Paulin [2003] study the meaning of the verb feel as a copula and C. Paulin [2003: 139-140] points out that in utterances such as The house feels cold or It feels like leather, the perception is dissociated from the experiencer:

L'énonciateur prend à sa charge le contenu propositionnel et s'il est déclencheur de la perception, celle-ci n'est pas l'objet du discours. [...] La perception y est dissociée du sujet-percevant pour être transmise au destinataire sous forme synthétique [...].

She adds that:

Feel [...] permet d'établir un lien entre le sujet grammatical et l'attribut. Il s'agit pour le sujet-énonciateur de définir le sujet de l'énoncé en lui attribuant une propriété sensorielle au sens large. Le verbe feel a ici une valeur modale et son sens se rapproche de celui de "be, with respect to a sensory modality ». On pourrait gloser ainsi : 
(29') To judge by its feel, the fabric is soft.

$\left(30^{\prime}\right)$ To judge by the feel of it, the whole affair is strange.

[L]e verbe de perception à emploi copule se comporte à la manière d'un auxiliaire modal à emploi épistémique. Comme lui, il porte sur l'ensemble de la relation prédicative dont il constitue le nœud prédicatif.

These quotes underline that with the copular construction, the perception of a particular experiencer is not salient, as if the sensory experience provided by the perceived were its objective property. The hypothesis defended in this contribution is that in that respect, have a feel completes the verb's semantic programme. To demonstrate this, the elements making up the periphrasis are considered below.

\subsection{The have a feel construction}

B. Cetnarowska [1993], following in H. Marchand's footsteps (cf. H. Marchand [1960]), observes that feel belongs to the deverbal nouns designating "'characteristic qualities of a thing as established by the verbal activity referred to': (velvety) feel, smell, touch (of a fabric) ". This approach consists in deriving the noun feel from the verb in its active sense, and it overlooks the link between the verb used as a copula and the deverbal noun. The hypothesis of a derivation from the copular verb is more convincing semantically.

The following subsections examine the role of each of the constituents of the periphrasis: have, the determiner $a(n)$ and the belonging of feel to the nominal category.

\subsubsection{Have}

P. Cotte [1997: 47-48] states that have codes the re-elaboration of the previous association of two entities:

En première analyse have marque l'inclusion. Entre deux référents perçus comme différents a lieu un repérage (une localisation). [...] Cependant l'inclusion ne saurait caractériser parfaitement have a car car elle sous-tend la possession, la signification typique de ce verbe, mais aussi l'appartenance, que dit par exemple belong; sous son rapport aucune différence n'existe entre I have a car (possession) et This car is mine (appartenance). C'est qu'elle ne concerne plus particulièrement ni le repère ni le repéré ; alors que nos exemples montreront que les énoncés en have ne sont pas neutres mais qu'ils s'intéressent surtout au repère de la localisation. On proposera donc que l'inclusion est seulement un donné pour diverses opérations énonciatives (thématisation, attribution, détermination) qui seules définissent have. Elle est un préconstruit, que have réélabore.

19 Applying this analysis to the structure under scrutiny suggests that the have a(n) ADJECTIVE feel structure is based on a cognitively prior utterance featuring the copulaverb feel; in other words, $X$ has a(n) ADJECTIVE feel follows from X feels ADJECTIVE; the latter establishes the link between the perceived and the sensation it triggers, and have reelaborates that link.

\subsubsection{Verb and noun}

The conversion of a verb to a noun has semantic consequences due to the types of meaning associated with nouns. R. Langacker [1991: 81] notes that verbs express "processual predications" and states that: 
A processual predication involves a continuous series of states $r 1, r 2, r 3, \ldots$, rn each of which profiles a relation; it distributes these states through a continuous span $t 1$, $\mathrm{t} 2, \mathrm{t} 3 \ldots . ., \mathrm{tn}$ of conceived time; and it employs sequential scanning for accessing this complex structure. [...] A process involves a series of relational configurations that necessarily extend through conceived time and are scanned sequentially thus defining its temporal profile. noun. Section 3 offers an analysis of the data collected in the Corpus of Contemporary American English.

\section{Feel and HAVE A(N) ADJECTIVE feel in the Corpus of Contemporary American English}

To test the validity of the hypotheses, examples drawn from the Corpus of Contemporary American English are examined below. 


\subsection{Adjectives occurring in the two constructions} constructions do not appear to be compatible with the same kind of adjectival meanings.

The queries made in the COCA are the following: it feels ADJECTIVE and has a(n) ADJECTIVE feel. ${ }^{1}$ It has been selected as a grammatical subject of the verb feel as the utterances where it is the subject correspond to cases where feel has the meaning examined (with other grammatical subjects, it would be necessary to check manually that all the utterances analyzed correspond to the meaning under scrutiny, which would not be feasible given the very high frequency of the verb). On the other hand, there are relatively few occurrences of the sequence has a feel, which warrants queries with no specific grammatical subject, so as to obtain a sufficient number of adjectives.

It is noteworthy that two types of constructions are to be found: $X$ has a(n) ADJECTIVE feel and $X$ has $a(n)$ ADJECTIVE feel to it - the difference between the two structures are analyzed in section 4.

The adjectives occurring at least 4 times with it feels are the following: ${ }^{2}$

good (554), great (117), different (33), real (33), strange (28), wonderful (28), wrong (24), weird (22), nice (19), natural (18), funny (12), comfortable (11), better (10), bad (10), safe (10), true (10), cold (9), unnatural (9), fine (8), awkward (7), new (7), smooth (7), warm (7), amazing (6), empty (5), dry (5), alive (5), important (5), impossible (5), incredible (5), normal (5), odd (5), silly (5), uncomfortable (5), awesome (5), cool (5), fantastic (4), full (4), lighter (4), okay (4), soft (4), solid (4), special (4).

The adjectives occurring at least twice in the structure has a(n) ADJECTIVE feel and has a(n) ADJECTIVE feel to it are the following:

similar (6), solid (5), good (5), retro (4), modern (3), certain (3), special (2), different (2), cozy (2), familiar (2), foreign (2), western / Western (2), claustrophobic (2), open (2), new (2), relaxed (2), roomy (2), nice (2).

\subsection{Semantic sets}

\subsubsection{It feels...}

For each semantic group, a list of adjectives and a few examples are provided.

Several adjectives occurring with the verb feel convey an appreciative meaning:

Group 1 - appreciative adjectives: awesome, better, fine, good, great, incredible, nice, wonderful; wrong, bad.

(01) TAMRON HALL So this is amazing your album drops today. [...] it has been called catchy, clever, gutsy, all of these things that are you. How does it feel?

ELLE KING It feels awesome. I ... I'm really excited. I can't believe I'm here. ( Today Show - "Self-proclaimed banjos swinging baby Elle King is one of music's rising stars", 2015) ${ }^{3}$

(02) You know, the overall growth over the past three and three-quarters years is the slowest in 50 years, lowest since the great depression, so it doesn't - there's not much question about why it feels bad because it is bad 
and, today, in general, the economy's dead in the water. (CNN_Moneyline,

"War Between the States Over Natural Gas", 1992)

\section{(sometimes in a metaphorical sense):}

Group 4: tactile properties and temperature: smooth, dry, soft; cold, warm, cool.

(06) Dough will be soft and slightly sticky to touch. If necessary, add more flour, 1 tablespoon at a time, and beat longer. Or with lightly oiled hands, knead dough in bowl until it feels smooth, pulls from your hands, and is just slightly sticky to touch, about 4 minutes. (Sunset, Linda Lau Anusasananan, "An old world Easter", Vol. 202, Issue 4, 1999)

(07) The front dining room is noisier and has a brasserie feel, with white marble tables, dining counter and storefront windows. It feels warm and cozy as diners see the flames and smell the seductive aromas of grilling steak, baking pizza and crisping chicken. (San Francisco Chronicle, Michael Bauer, "Remodeled Bistro Aix still shines", 2010)

(08) "I have no idea how to use this thing," I say. "You mean you've never fired a gun before? Oh, I forgot you're a city boy. You're just used to seein' the business end pointin' at you."

"I've shot at a rifle range before -"

"Well, this ain't no different. Just aim and pull the trigger. She's already loaded."

I take the gun in my hands. It feels cold, solid, heavy. Good. It makes me bold. ( The Antioch Review, Rubin, Richard, “Decoys”, Vol. 54, Iss. 4, 1996 Fall)

Two other groups can be identified:

Group 5: full / empty.

(09) You change your vacuum bag... when it feels full. Vacuuming once a week will keep dust from accumulating deep in carpets, but the bag will fill up fast. A full bag reduces efficiency and can even spew dust back into the air. ( Prevention, Amanda MacMillan, "Find Your Breathing Room", Vol. 59, Iss. 11, Nov. 2007) 
Group 6: safe / dangerous.

(10) There are other reasons the entertainer loves coming home to Denver. "I love the change of seasons," she says. "I didn't have that in Los Angeles, and New York didn't offer much sky... Here, I go to the cleaners, and I know them. I go to the grocery store, and I went to school with some of them. Everything is five minutes away, and it feels safe and good and wonderful and warm." (Denver Post, Elana Ashanti Jefferson, 2008)

Those examples show that, contrary to what is suggested by the definitions and the paraphrase mentioned earlier, the copular verb feel has at least three distinct meanings: - Type 1. (1) It feels awesome $\Leftrightarrow>$ I feel awesome to know that my album is said to be called catchy, clever, gutsy.

- Type 2. (2) It feels bad $<\Rightarrow>$ People feel ( $\approx$ think) that the economy is bad.

- Type 3. (6) The dough feels smooth $\Leftrightarrow=>$ When I touch the dough, I feel something soft $\rightarrow$ The dough is soft to the touch.

Only the third type corresponds to the gloss generally given of feel in its copular use. The same construction covers three degrees on a subjective-objective scale: type 1 utterances are about the experiencer's state of mind; type 2 utterances deal with a general opinion about an object; type 3 utterances are the most objective in the sense that they are those dealing with the tactile properties of the object perceived.

Figure 2. Meaning of copular feel

\begin{tabular}{|l|l|l|}
\hline \multicolumn{2}{|l|}{ Objective property } & \multicolumn{2}{l|}{ Subjective experience } \\
\hline-0 & It feels awesome \\
\hline The dough feels smooth & It feels bad & (Type 1) \\
\hline (Type 3) & (Type 2) & \\
\hline
\end{tabular}

\subsubsection{Has a(n) ADJECTIVE feel}

41 This section deals with the adjective occurring in the structure has a(n) ADJECTIVE feel apart from the adjectives appearing only in the has a(n) ADJECTIVE feel to it construction.

42 Here again, it is possible to distinguish several semantic types among those adjectives: Group 1: evaluative adjectives: great, good, wonderful.

(11) Once you've mastered the Rubik's Cube, you almost can do it with your eyes closed, but we are intrigued by The Void Puzzle (\$15.95), the standard cube with a hole in the middle where the center colors should be. You can see right through it; there doesn't appear to be any mechanism in there. So how does it turn? We don't know, but it has a great feel and the movements are smooth. (USA Today Magazine, "What's New?", July 2012, Vol. 141, Issue 2806)

Group 2: tactile properties: worn-in, special. 
(12) Brands are producing trouser styles and denim shorts in this more masculine daytime pattern for warmer weather. "Our washed, striped denim flared leg is a fresh take on the classic blue jean this summer," explains Rick Spielberg, vice president of Hudson Jeans. "It is ultrasoft and lightweight, and it has a worn-in feel." (Harpers Bazaar, "Denim Special: For Every Age", Issue 3558, May 2008)

\section{Group 6: certain, different, similar.}

(19) APPLEGATE: And that's what's unique, I guess, about this kind of fat, is that it has a certain feel in your mouth. There's like a feeling of melting or something that is sort of appealing, I guess. (NBC_Today, "Nutritionist Joy Bauer Explains Good Fatty Foods and Those Fatty Foods We Should Avoid", 2000).

(20) It was the world's most famous nightclub, a cauldron of sex, drugs and disco. Three decades later, Studio 54 has a very different feel. (NBC Today Show, 
“We've been talking about this woman for about four years now, Rachelle

Friedman Chapman", 2015) mind. (cf. examples (1) et (1')). The verb expresses what the experiencer feels in a particular situation, whereas the substantive is the record of a categorization established previously and which applies to the object perceived. This may be why the substantive is compatible with adjectives referring to style. It occurs frequently as an advertising claim, as it is not about what the speaker feels in a particular place, but about how the reader is bound to feel, in virtue of the properties of the perceived. ${ }^{4}$ of the substantive is excluded when the speaker deals with his or her own experience or when the utterance is about a temporary characteristic of the perceived, hence the incompatibility of the substantive with full and empty (cf. examples (21) and (21')).

This analysis is validated by the two following manipulations:

(22) Steering is extremely quick, but rather heavy. The firm, highperformance suspension provides confident handling but causes a jumpy 
ride on broken or wavy pavement. (Car buffs will expect this.) The brake pedal has a solid feel, and the oversized brakes provide sure stopping. (Chicago Sun-Times, Dan Jedlicka, "Relatively inexpensive Caliber SRT4 offers bang for the buck", 2008)

(22') The brake pedal feels solid. evaluates the resistance of the pedal, whereas example (22') refers to the driver's impression when he or she puts his or her foot on the pedal.

(11) Once you've mastered the Rubik's Cube, you almost can do it with your eyes closed, but we are intrigued by The Void Puzzle (\$15.95), the standard cube with a hole in the middle where the center colors should be. You can see right through it; there doesn't appear to be any mechanism in there. So how does it turn? We don't know, but it has a great feel and the movements are smooth.

(11') but it feels great.

Example (11) refers to the toy's ergonomy; (11') is about the player's state of mind while manipulating the Void Puzzle, typical of a type 1 use of the verb feel.

\subsection{To summarize}

The verb denotes personal experience anchored in a particular situation; the substantive hides the personal substrate underlying that experience to present the feeling as emanating from the perceived, so that the two structures convey different meanings. It is noteworthy that the verb feel, even when the grammatical subject is inanimate and is logically what the utterance is about, can express how the experiencer feels.

The substantive does not take this personal substrate into account and has to do with more objective data: an atmosphere, but also a style, and stable properties, such as the ergonomy of an object, so that it constitutes the ultimate stage of a process of objectification, as it separates the perceived property from the perception itself, which is in keeping with its belonging to the nominal category, as defined by R. Langacker [1991] for instance. The overlapping between the meaning of the two lexemes is therefore limited.

\section{X has a(n) ADJECTIVE feel to it}

This section examines the construction $X$ has a(n) ADJECTIVE feel to it.

The following table compares the number of occurrences of $X$ has a(n) ADJECTIVE NOUN ${ }^{5}$ and $X$ has a(n) ADJECTIVE NOUN to it constructions with the five perception nouns (smell, taste, look, sound and feel).

Table 1: Comparison between has a(n) ADJ smell / taste / look / sound / feel and has a(n) ADJ smell taste / look / sound / feel to it

\begin{tabular}{|l|l|}
\hline Constructions & Number of occurrences \\
\hline Has a (n) ADJECTIVE smell & 45 \\
\hline
\end{tabular}




\begin{tabular}{|l|l|}
\hline Has a $(n)$ ADJECTIVE smell to it & $1(2 \%)$ \\
\hline Has a (n) ADJECTIVE taste & 43 \\
\hline Has a(n) ADJECTIVE taste to it & $1(2 \%)$ \\
\hline Has a (n) ADJECTIVE look & 192 \\
\hline Has a (n) ADJECTIVE look to it / her / him, etc. & $7(3.6 \%)$ \\
\hline Has a (n) ADJECTIVE sound & 41 \\
\hline Has a (n) ADJECTIVE sound to it & $5(12 \%)$ \\
\hline Has a $(n)$ ADJECTIVE feel & 131 \\
\hline Has a $(n)$ ADJECTIVE feel to it & $28(21 \%)$ \\
\hline
\end{tabular}

The table only takes into account the utterances with an inanimate grammatical subject (utterances such as have a look at that! have been left out), except in the case of look, where animate grammatical subjects can also be relevant.

61 These figures show that feel - and, to a lesser extent, sound - is much more compatible with the use of the prepositional phrase than the nouns referring to other sense modalities. The PP appears in a fifth of all the occurrences of have a feel, whereas it is marginal with smell, taste and look.

\subsection{Adjective occurring in the construction X HAVE a(n) ADJECTIVE feel to it}

The adjectives occurring in the X HAVE a(n) ADJECTIVE feel to it construction are the following: aeronautical, cavernous, certain, closer, depressing, deserted, different, easy, empty, familiar, global, good, informational, innocent, lunar, masculine, mysterious, nasty, natural, nice, nicer, open, organic, parisian, pleasant, populist, private, ramshackle, redemptive, relaxed, religious, retro, rhetorical, roomy, short-term, similar, solid, static, timeless, unpleasant, silky, similar, suburban, weird. ${ }^{6}$

They are found in utterances such as:

(23) Because he knew where to look, Denny could see its faint outline, blacker than the night sky. The place had a deserted feel to it; now that he had it in view, he was ready to bet that nobody, Hefn or human, waking or sleeping, was inside. (Fantasy \& Science Fiction, Judith Moffet, "The Bear's Baby”, Oct / Nov 2003)

(24) Although a few of the authors expressed optimism for the future, the history of the field has a depressing feel to it, one that indicates the continuation of status quo practices with a few bursts of creativity now and then. (Social Studies, Zevin, J., "Teachers in social studies education”, Nov / Dec 1990, Vol. 81 Issue 6)

The structure X HAVE a(n) ADJ feel to it covers a more limited ground than its counterpart without the prepositional phrase; it is used to depict an atmosphere, but does not deal 
with ergonomy and refers only marginally to tactile properties. In other words, it limits itself to the impression emanating from the perceived.

\subsection{Genesis of the construction}

P. Cotte comments on structures following the pattern HAVE NOUN PHRASE PREPOSITION PRONOUN. He states that (cf. P. Cotte [1998: 418]):

Dans l'énoncé The garden has a wall around it le syntagme prépositionnel final constitue une trace du rapport d'inclusion. Cette inclusion étant préconstruite, on ne doit pas considérer que le verbe est entouré de trois, mais de deux constituants de même niveau : le sujet et la séquence $a$ wall around it, qui est attribué en bloc à ce dernier au moyen de have.

and adds (cf. P. Cotte [1997: 50]):

Parfois un syntagme prépositionnel explicite l'association initiale quand elle est contingente. Ainsi She had a baby with her provient de A baby was with her ou de There was a baby with her. Ce premier énoncé est rapporté par have au repère de l'inclusion, qui est mentionné deux fois dans le nouvel énoncé (cf. She et her).

67 According to that analysis, the genesis of the structure X HAVE a(n) ADJECTIVE feel to it is therefore There is a(n) ADJECTIVE feel to $X$, which is then re-elaborated by have. This explains why the utterances featuring that construction focus on the atmosphere attached to the referent of the grammatical subject: the feel in question is endowed with a certain autonomy, in virtue of its nominal status of feel and of the construction itself ("there is"), so that the construction cannot refer to the most objective properties (tactile qualities, ergonomy) otherwise conveyed by nominal feel. In other words, the impression conveyed by the perceived is presented as maximally severed from its source, and it is reattributed to it through the use of have. With this structure, the autonomy of the property ascribed to the perceived is maximal: copular feel and the structure have a feel detach the property from the perceived of the experiencer; the have a feel to it construction also detaches it from the perceived itself. ${ }^{7}$

\section{Conclusion}

This contribution shows that three constructions that appear to be semantical equivalent do not admit the same collocations, which suggests that they have different semantic orientations.

The same principle seems to be at play in the evolution of the meaning of the verb and of the noun: the copular use of the verb admitting the referent of the perceived as its grammatical object appeared after its use as referring to personal experience; the use of the noun referring to the objective properties of the perceived is also more recent than its meaning of personal experience. In both cases, the most recent meaning consists in the objectification of a personal impression, but the noun goes further in that direction because of its very nominal nature, and the X HAVE a(n) ADJECTIVE feel to it constitutes the climactic stage of the autonomy of the property ascribed to the perceived.

The evolution of the two lexemes may rest on the notion that individual experience is based on an extralinguistic reality shared by many speakers, which gives that experience a validity that goes beyond purely subjective sensations or emotions. 
71 This would explain why historically the copular verb and the noun in their "objective" meaning were first related to physical properties (cf. sections 1.1 and 1.2) and only later with affects: the sensations brought about by the perceived have been thought to be common to experiencers before the feelings triggered by a place or a situation. This hypothesis would also account for the late appearance of the structure have a(n) ADJECTIVE feel to it - depicting an atmosphere or a general impression - whose first occurrence in the Corpus of Historial American English (COHA) dates back to 1959.

\section{BIBLIOGRAPHY}

CETNARowsKa Bozena, 1993, The Syntax, Semantics and Derivation of Bare Nominalisations in English, Katowice: Uniwersytet ŚlĄski.

COTTE Pierre, 1998, «HAVE n'est pas un verbe d'action : l'hypothèse de la réélaboration », in ROUSSEAU André (ed.), La transitivité. Villeneuve d'Ascq : Presses Universitaires du Septentrion, 415-439.

Сотте Pierre, 1997, Grammaire linguistique. Paris : Didier Érudition.

DAVIES Mark, 2008-, The Corpus of Contemporary American English: 560 million words, 1990-present, available at http://corpus.byu.edu/coca/

DAVIES Mark. (2010-) The Corpus of Historical American English (COHA): 400 million words, 1810-2009, available online at https://corpus.byu.edu/coha/

GISBORNE Nikolas, 1993, "Nominalizations of perception verbs", UCL Working Papers in Linguistics 5, 23-24.

LACASSAIN-LAGOIN Christelle, 2012, «It's not what it looks to be! : Déconnexion entre forme et sens dans les énoncés avec verbe de perception à emploi dit "copule" ", E-rea, 9.2, disponible à http:// erea.revues.org/2437

LANGACKER Ronald, 1991, Concept, Image, and Symbol, The Cognitive Basis of Grammar, Berlin/New York: Mouton de Gruyter.

MARCHAND Hans, 1960, The Categories and Types of Present-Day English Word-Formation, Wiesbaden: Otto Harrassowitz.

Online Etymology Dictionary, available at https://www.etymonline.com

Oxford English Dictionary, available at http://www.oed.com

PAULIN Catherine, 2003, « Polysémie et complémentation verbale : le verbe feel dans tous ses états ", in Delmas Claude, Roux Louis (eds.), Correct, Incorrect en linguistique anglaise C.I.E.R.E.C, Travaux 113, Publications de l'Université de Saint-Étienne Jean Monnet, 129-155.

PLAG Ingo, 2003, Word-formation in English, Cambridge: Cambridge University Press.

SOUESME Jean-Claude, 2015, « Les suites lexicales composées de have a + nom éventuellement précédé d'un adjectif », Lexis, 9, 79-93. 
WIERZBICKA Anna, 1982, “Why can you have a drink when you can't *have an eat?”, Language, Vol.

58, No. 4, Dec., 753-799.

\section{NOTES}

1. Only one verbal form has been selected in order to avoid several mentions of the same adjective, and the present form has been chosen because it is the most frequent in the HAVE a $(n)$ ADJECTIVE feel construction.

2. The figures in brackets correspond to the number of occurrences found in the COCA.

3. In all the examples, drawn from the COCA, the emphasis is mine.

4. Significantly, has a(n) ADJECTIVE feel is more frequent in the COCA's magazine and newspaper subcorpora ( 0.56 occurrences per million words) than in the spoken ( 0.10 occurrences per million words), fiction ( 0.10 occurrences per million words) or academic subcorpora (0.06 occurrences per million words), and appears essentially in the life and sports sections.

5. The first line, for each of the nouns, includes the total number of relevant occurrences of $X$ has a(n) ADJECTIVE NOUN \# and X has a(n) ADJECTIVE NOUN to it (or another personal pronoun in the case of look).

6. The construction being infrequent, there are few occurrences of each adjective in that structure (between one and four occurrences), which is why all the forms of have have been chosen; selecting only the present form does not yield enough results.

7. J.-C. Souesme [2015: 92] notes that “*This letter has a stamp n'est pas acceptable, alors que : (44) This letter has a stamp on it est correct. Le fait d'ajouter on it renvoie à la situation initiale, spécifique, celle de la situation d'énonciation ; cela permet d'attribuer au référent du sujet un état particulier; on se situe donc du côté qualitatif : la lettre en question est timbrée, donc prête à partir. On ne réfère pas à une propriété de cette enveloppe, qui serait, et donc aurait été, observable en toute circonstance. De même : (45) This table has a scratch on it implique que la table est dévaluée en raison de la rayure en question. On a donc affaire à une propriété associée. Inversement : (46) ? This table has a lamp on it sera considéré comme douteux par les anglophones : le fait qu'une lampe soit posée sur la table ne permet pas de conférer à cette dernière une propriété spécifique particulière». This analysis differs from the theory defended by P.Cotte [1997] and [1998], but its implications are in keeping with the phenomena observed with feel: only contingent - and not intrinsic - qualities are attributed to the grammatical subject.

8. This would also explain why the construction is also relatively frequent with sound, as the sound is not conceived as an intrinsic quality of a particular entity, unlike its look, taste or smell. (cf. C. Lacassain [2012] : “[...] le son n'est pas une propriété intrinsèque d'une entité (alors que celle-ci a une apparence, une odeur, un goût ou un toucher inhérent)".

\section{ABSTRACTS}

This paper analyzes the verb feel in its use as a copula and the substantive feel in the phrases $X$ HAVE a(n) ADJECTIVE feel and X HAVE a(n) ADJECTIVE feel to it when the grammatical subject designates a non-animated entity. Those constructions, which are connected with perceptions and emotions, have very similar meanings, however, the study of the contexts in which they 
appear invalidates the hypothesis of their strict equivalence, and in many utterances, the verb and the periphrases X HAVE a(n) ADJECTIVE feel or X HAVE a(n) ADJECTIVE feel to it have strikingly different meanings or are not interchangeable.

This paper focuses on the collocations formed by the verb and the substantive, and aims to demonstrate that the verb is linked with subjective experience anchored in a specific situation. The substantive, on the other hand, is at one remove from subjective experience, and refers to codified sensations and emotions (as suggested, for example, by its high compatibility with adjectives referring to style). This contribution defends the hypothesis that the meaning of the substantive studied here reflects the objectification of perception which results from the historical evolution of the verb and the noun. The emergence of the phrase HAVE a(n) ADJECTIVE feel to it is the last step of that objectification.

Cette contribution porte sur le verbe feel dans son emploi de verbe copule, ainsi que sur que le substantif feel dans les séquences X HAVE a(n) ADJECTIVE feel and X HAVE a(n) ADJECTIVE feel to it lorsque le sujet grammatical désigne une entité inanimée. Ces constructions, liées aux perceptions et aux émotions, ont des sens très proches, néanmoins, l'étude des contextes dans lesquels elles apparaissent invalide l'hypothèse de leur stricte équivalence sémantique, et, dans de nombreux énoncés, le verbe feel et les périphrases X HAVE a(n) ADJECTIVE feel ou X HAVE a(n) ADJECTIVE feel to it ont des sens différents ou ne sont tout simplement pas interchangeables.

Nous analysons les collocations formées par le verbe et le substantif et cherchons à démontrer que le verbe est en lien avec une expérience subjective ancrée dans une situation spécifique, tandis que le substantif est en décalage avec cette expérience directe et renvoie à des sensations et émotions codifiées, comme l'atteste notamment sa forte compatibilité avec les adjectifs désignant un style. Nous défendons la thèse que la signification du substantif étudiée ici correspond à une objectivisation de la perception qui marque l'aboutissement d'une évolution historique du sémantisme du verbe et du nom. L'émergence de la construction X HAVE $a(n)$ ADJECTIVE feel to it en marque la dernière étape.

\section{INDEX}

Keywords: feel (verb), feel (substantive), parts of speech, sensations, perceptions, emotions, affects

Mots-clés: feel (verbe), feel (nom), parties du discours, sensations, perceptions, émotions, affects

\section{AUTHOR}

\section{STÉPHANIE BÉLIGON}

Sorbonne Université

stephanie.beligon@sorbonne-universite.fr 